\title{
Pore network of an Inceptisol under different uses and relativized S-index as an indicator of soil physical quality
}

\author{
Raimundo Nonato de Assis Júnior(1), Jaedson Cláudio Anunciato Mota(1), \\ Alcione Guimarães Freire ${ }^{(1)}$ and Thiago Leite de Alencar ${ }^{(1)}$
}

\begin{abstract}
(1)Universidade Federal do Ceará, Centro de Ciências Agrárias, Departamento de Ciências do Solo, Campus do Pici, Avenida Mister Hull, n².977, CEP 60356-001 Fortaleza, CE, Brazil. E-mail: assisjr@ufc.br, jaedson.mota@ufc.br, alcionegf@hotmail.com, thiagoleitealencar@ yahoo.com.br
\end{abstract}

\begin{abstract}
The objective of this work was to evaluate soil porous media quality under different uses, as well as to propose a new index to monitor changes in its structure due to management: the $\mathrm{S}_{\text {relative }}$ index. An Inceptisol under irrigated banana cultivation and secondary forest, in the Brazilian Apodi Plateau, was evaluated at three soil layers $(0.0-0.1,0.1-0.2$, and $0.2-0.3 \mathrm{~m})$ as to: particle size, particle and bulk density, organic matter content, intrinsic permeability to air, and water retention curve. Total porosity, index for pore continuity (defined by the ratio between soil intrinsic permeability to air and aeration porosity), volume of blocked pores, and the $\mathrm{S}$ and $S_{\text {relative }}$ indices were determined. The $S_{\text {relative }}$ index was calculated as the ratio between S-index values from undisturbed and disturbed samples of the same soil $\left(\mathrm{S}_{\text {undisturbed }} / \mathrm{S}_{\text {disturbed }}\right)$. Under the studied conditions, the $\mathrm{S}_{\text {relative }}$ index is a good quantifier of the changes imposed by soil use and management. Soil cultivation maintains or improves the quality of the evaluated attributes, except for blocked porosity, when compared with the soil under native secondary forest with ten years of regeneration after agricultural use.

Index terms: blocked porosity, irrigation management, pore continuity, soil management, soil permeability to air, $\mathrm{S}_{\text {relative }}$ index.

\section{Rede de poros de um Cambissolo sob diferentes usos e índice $S$ relativizado como indicador da qualidade física do solo}

Resumo - O objetivo deste trabalho foi avaliar a qualidade do meio poroso de solo submetido a diferentes usos, bem como propor um novo índice para monitorar mudanças em sua estrutura devidas ao manejo: o índice $\mathrm{S}_{\text {relativo }}$. Um Cambissolo sob cultivo de banana irrigada e mata secundária, na Chapada do Apodi, foi avaliado em três camadas $(0,0-0,1,0,1-0,2$ e $0,2-0,3 \mathrm{~m})$, quanto a: granulometria, densidade de partículas e do solo, conteúdo de matéria orgânica, permeabilidade intrínseca ao ar e curva de retenção de água. Foram determinados porosidade total, índice de continuidade dos poros (definido pela razão entre a permeabilidade ao ar e a porosidade de aeração), volume de poros bloqueados, e índices $S$ e $S_{\text {relativo. }} O$ índice $S_{\text {relativo }}$ foi calculado como a razão entre os valores do índice $\mathrm{S}$ em amostras indeformadas e deformadas de um mesmo solo $\left(\mathrm{S}_{\text {indeformada }} / \mathrm{S}_{\text {deformada }}\right)$. Nas condições estudadas, o índice $S_{\text {relativo }}$ mostra-se como um bom quantificador das alterações impostas pelo uso e pelo manejo do solo. O cultivo do solo mantém ou melhora a qualidade dos atributos avaliados, exceto para porosidade bloqueada, em comparação ao solo sob mata secundária com dez anos de regeneração após uso agrícola.

Termos para indexação: porosidade bloqueada, manejo da irrigação, continuidade de poros, manejo do solo, permeabilidade ao ar, índice $S_{\text {relativo. }}$.

\section{Introduction}

Although it is largely accepted that soil quality is a consequence of biological, chemical, and physical aspects, the latter are often neglected. This, according to Dexter (2004), is a great misconception, since the decrease in soil physical quality, which is widespread in agricultural areas, affects both chemical and biological conditions. These soil conditions, moreover, require information on physical aspects in order to be fully interpreted. In this context, the inclusion of visual indicators is recommended for the assessment of soil quality (Giarola et al., 2010).

Therefore, the research effort in seeking indicators or reference values to analyze soil physical quality for agricultural purposes has been intense. The following 
critical values of soil physical attributes, for instance, have been suggested: $2 \mathrm{MPa}$ for resistance to root penetration, $10 \%$ for aeration porosity (Beutler et al., 2006), and $1 \mu \mathrm{m}^{2}$ for soil intrinsic permeability to air (Ball et al., 1988).

The S-index proposed by Dexter (2004) is commonly used as a soil quality indicator. Mathematically, it is defined as the slope of the tangent line to the inflection point of the soil water retention curve, traced according to the gravimetric water content $(\mathrm{w})$ and to the natural logarithm of the soil water matric potential $(\ln h)$. Physically, it is associated with the soil structure, since it separates the effects of soil structure and texture in the soil water retention curve. Dexter \& Czyz (2007) defined soil quality categories for the S-index, namely: $S<0.020$, very poor; $0.020 \leq S<0.035$, poor; $0.035 \leq S<0.05$, good; and $S \geq 0.05$, very good.

Implicitly, the S-index assumes unimodal pore radius distribution and, therefore, it cannot be considered for soils with bimodal or multimodal pore radius distribution (Carducci et al., 2011). For van Lier (2014), the theoretical basis of the S-index is conceptually interesting, albeit it should not create expectations that the S-index, like an absolute index, is able to predict soil physical quality by itself. The author also emphasizes that the commonly used limit value of $S=0.035$ has no basis under the various boundary conditions described in the literature.

It should be noted that small changes in the S-index may cause substantial change in the quality attributed to the soil, which may not correspond to reality. Therefore, it is reasonable to consider that the S-index and other indicators still need adjustments in order to become real indicators of changes in soil structure. Relativizing these indexes, as has been done for soil density (Zhao et al., 2010), may prove a good alternative to cope with these deficiencies. The relativized S-index, here called $S_{\text {relative, }}$ is obtained from the ratio between the S-index, calculated from undisturbed and disturbed samples of the same soil - that is, with the same texture -, allowing for quantitative inference on the effects of management on soil structure. Among the advantages of the $S_{\text {relative }}$ index, is the fact that it does not require indicative ranges of soil quality, as does the S-index, which makes it applicable to evaluate alterations in the structure of any soil, regardless of the uses and managements to which it is subjected to.
The objective of this work was to evaluate soil porous media quality under different uses, as well as to propose a new index to monitor changes in its structure due to management: the $S_{\text {relative }}$ index.

\section{Materials and Methods}

The study area is located at the Apodi Plateau, in the state of Ceará, Brazil, and has been uninterruptedly cultivated with banana (Musa sp.) for eight years. A contiguous preserved area of secondary native forest, once used for agricultural purposes ten years before, was taken as check. The areas under banana cultivation and secondary native forest had 3 and 0.5 ha, respectively, and were $5 \mathrm{~m}$ apart from each other. The soil is classified as a Cambissolo (Inceptisol), and water and nutrient supply for the crop were delivered through drip fertigation.

Disturbed and undisturbed soil samples were taken in the $0.0-0.1,0.1-0.2$, and $0.2-0.3-\mathrm{m}$ soil layers. Undisturbed soil samples were collected with an Uhland sampler, in steel rings $(0.05-\mathrm{m}$ height $\mathrm{x}$ 0.05-m diameter), with five replicates. Samplings were performed in the central part and in the four corners of the experimental areas, excluding the lateral borders.

The particle size analysis was performed with the pipette method, whereas total porosity was calculated according to the results of particle density and soil bulk density. Particle density was determined using a volumetric flask; and soil bulk density, using undisturbed soil samples. Organic carbon was also determined, according to the method proposed by Yeomans \& Bremmer (1988). Soil permeability to air was obtained based on Silva et al. (2009): a volume of air with 1,000-Pa pressure was passed through the volumetric rings containing undisturbed soil samples, in equilibrium with the water tensions of $2,6,10,33$, and $100 \mathrm{kPa}$.

The soil water retention curve was obtained considering the water content at a saturation equal to soil porosity. At the low tension points $(2,4,6,8$, and $10 \mathrm{kPa})$, water content was determined using a Haines funnel, and, at the higher ones (33, 100, 300, $700,1,000$, and $1,500 \mathrm{kPa}$ ), using a Richards pressure chamber with porous plate (Klute, 1986). The fitted curve was obtained using the mathematical model proposed by van Genuchten (1980). The curve of cumulative pore-size frequency, or pore distribution 
curve, was obtained by the ratio $\theta / \alpha$ - in which $\theta$ is the volumetric water content and $\alpha$ is total porosity - for each matric potential applied in the construction of the soil water retention curve (Libardi, 2012).

The S-index was determined according to Dexter (2004), but the proposed $S_{\text {relative }}$ indicator was used to assist in its interpretation. The S-index is calculated with the soil water retention curves obtained for undisturbed (regular method) and disturbed (for $\mathrm{S}_{\text {relative }}$ ) soil samples, whereas the $S_{\text {relative }}$ index is obtained from the ratio $\mathrm{S}$-index undisturbed $_{\mathrm{S}} / \mathrm{S}$-index $\mathrm{disturbed}_{\text {. }}$

The disturbed soil samples were air-dried after passing through a 10-mesh sieve, then they were accommodated in rings with the same dimensions as those used for collecting the undisturbed samples. The accommodation must be done in a way that the soil particles are naturally arranged in the rings, without using a predefined value for soil density. It should be pointed out that, since the material was sieved, the accommodation of the material inside the cylinder occurs in such a way that the pores in it resemble the textural pores, obtained from the natural arrangement of the individual particles of sand, silt, and clay.

Sieved soil was used in the present study, since this is the same material employed in most of the chemical and physical analyses, including the soil water retention curve at lower potentials, in which the effect of soil structure on water retention is negligible (Reichardt \& Tim, 2012).

Values of soil intrinsic permeability to air $\left(\mathrm{K}_{\text {air }}\right)$ were related to aeration porosity values $\left(\varepsilon_{\text {air }}\right)$ using the Kozeny-Carman equation, similarly to what was done in the procedure adopted by Ball et al. (1988): $\mathrm{K}_{\mathrm{air}}=\mathrm{M} \varepsilon_{\text {air }}{ }^{\mathrm{N}}$, which can be written as $\log \mathrm{K}_{\text {air }}=\log \mathrm{M}$ $+\mathrm{N} \log \varepsilon_{\text {air }}$, in which $\mathrm{M}$ and $\mathrm{N}$ are empirical fitting parameters. In this case, the $\mathrm{N}$ value was considered as a pore continuity index that reflects either the increase in $\mathrm{K}_{\text {air }}$ with increasing $\varepsilon_{\text {air }}$, or the decrease in pore tortuosity and surface area with increasing pore fraction available for flow. Aeration porosity corresponds to the difference between total porosity and the water content measured at each potential.

The limiting air permeability (intercept in the " $x$ " axis or in the "log $\varepsilon_{\text {air }}$ " axis) was defined as $1 \mu \mathrm{m}^{2}$, a value suggested by Ball et al. (1988) as the volume of blocked pores in the soil $\left(\varepsilon_{\mathrm{b}}\right)$ that does not contribute to the convective transport of air. Therefore, $\varepsilon_{\mathrm{b}}$ is the value of $\varepsilon_{\text {air }}$ below which the air flow through the soil ceases as a consequence of the discontinuity in the aeration pore network. The $\varepsilon_{\mathrm{b}}$ value is obtained with the following equation: $\varepsilon_{\mathrm{b}}=10^{(-\log M) / \mathrm{N}}$.

Groenevelt et al. (1984) also proposed a pore continuity index that is based on the ratio between $\mathrm{K}_{\text {air }}$ and $\varepsilon_{\text {air }}$, i.e., $\mathrm{K}_{1}=\mathrm{K}_{\mathrm{air}} / \varepsilon_{\text {air }}$.

As for the S-index, Dexter \& Czyz (2007) recommended that it should be considered the slope of the tangent line to the inflection point of the van Genuchten equation, traced with the gravimetric water content $(\mathrm{w})$ and the natural logarithm of the soil water matric potential $(\ln \mathrm{h})$, according to the equation:

$$
\mathrm{S}=-\mathrm{n}\left(\mathrm{W}_{\mathrm{sat}}-\mathrm{W}_{\text {res }}\right)[1+1 / \mathrm{m}]^{-(1+\mathrm{m})}
$$

The dataset was analyzed considering a completely randomized statistical design, in a split-plot arrangement (cultivation systems and layers), with five replicates. The following tests were applied: the Kolmogorov-Smirnov test to verify data normality, the F-test for the analysis of variance, and Tukey's test to compare means, all at 5\% probability, using the Assistat program (Silva, 2013).

\section{Results and Discussion}

The $0.0-0.3-\mathrm{m}$ soil layer showed $26 \%$ sand, $39 \%$ silt, and $35 \%$ clay under cultivation; however, under native secondary forest, the same layer showed values of 28,31 , and $41 \%$, respectively. For the $0.0-0.1$, $0.1-0.2$, and $0.2-0.3-\mathrm{m}$ soil layers, soil organic matter contents in the native forest were 62,32 , and $25 \mathrm{~g} \mathrm{~kg}^{-1}$, respectively, which were higher than the values found in the cultivated area, which were 30,27 , and $24 \mathrm{~g} \mathrm{~kg}^{-1}$, respectively.

For the cultivated soil, the relation between soil intrinsic permeability to air and matric potential was linear, whereas, for the secondary forest soil, it was logarithmic (Figure 1). Therefore, the same mathematical model cannot be applied to adjust the data for both areas. Costa et al. (2014), while evaluating a Cambissolo (Inceptisol) located in the same region of the present study, also observed that $\mathrm{K}_{\text {air }}$ data versus the matric potential fitted well to a logarithmic model. Indeed, $\mathrm{K}_{\text {air }}$ values increased with the reduction in soil water contents, in response to higher pore volumes and to the formation of preferential paths for air flow as smaller-sized pores were progressively drained (Silva et al., 2009).

Pesq. agropec. bras., Brasília, v.51, n.9, p.1575-1583, set. 2016 DOI: 10.1590/S0100-204X2016000900057 
For the cultivated area, at least in the studied water range from the established matric potentials, the less wet the soil gets, the greater is the area available for gas diffusion. However, in the area under secondary native forest, soil drying does not increase soil permeability to air in the same proportion, showing increasingly smaller increments of available area for air flow, for the same variation in the soil water matric potential.

The linear ratio between soil intrinsic permeability to air $\left(\log \mathrm{K}_{\text {air }}\right)$ and aeration porosity $\left(\log \varepsilon_{\text {air }}\right)$ showed good adjustment $\left(\mathrm{R}^{2}>0.84\right)$ for both soils and all layers (Figure 2). Similar relationships were reported by Ball et al. (1988), Dörner \& Horn (2006), and Berisso et al. (2013). It should be highlighted that the angular coefficient $(\mathrm{N})$ from the log-log relationship between the $\mathrm{K}_{\text {air }}$ and $\varepsilon_{\text {air }}$ variables is considered an indicator of soil physical quality. Physically, it represents the rate of increase or reduction of connected pores as aeration porosity increases or decreases (Ball et al., 1988). Comparatively, the slope was greater in the soil under banana, showing a better pore connection.

The cultivated soil, despite its better pore network quality, showed a very small value for $\log \mathrm{K}_{\text {air }}$, on the order of $6 \mu \mathrm{m}^{2}$ (Figure 2), which is close to the limit of blocked porosity, of $1 \mu \mathrm{m}^{2}$ (Berisso et al., 2013), when $\log \varepsilon_{\text {air }}$ was $0.1 \mathrm{~m}^{3} \mathrm{~m}^{-3}$ - the limiting aeration porosity for plants (Beutler et al., 2006). This suggests the need for a careful monitoring of the porous fraction of this soil. Similarly, Rodrigues et al. (2011), when
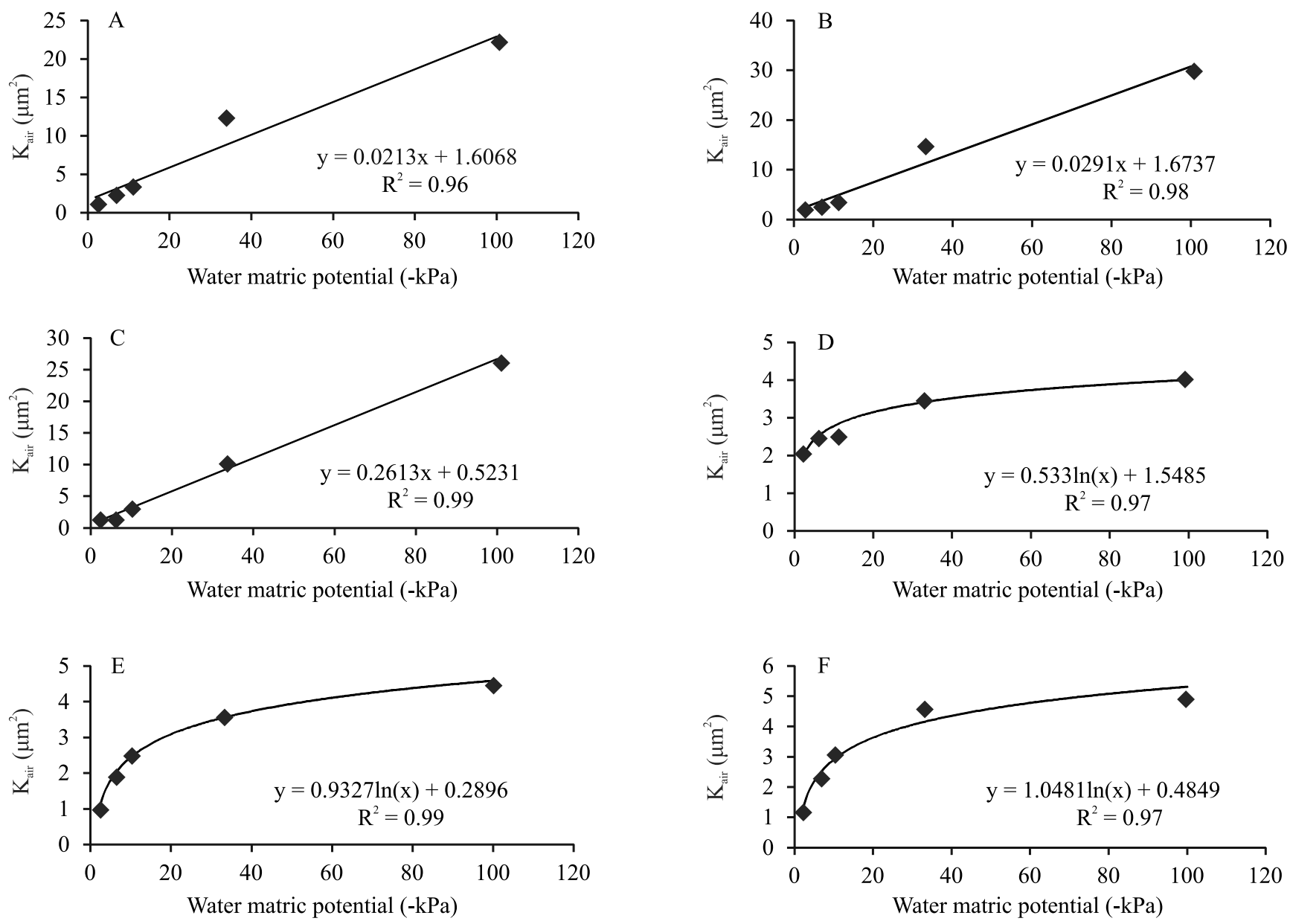

Figure 1. Soil permeability to $\operatorname{air}\left(\mathrm{K}_{\text {air }}\right)$ as a function of the water matric potential of an Inceptisol in the layers: A, 0.0-0.1 m; B, 0.1-0.2 m; and C, 0.2-0.3 m, under cultivation with banana (Musa sp.); and D, 0.0-0.1 m; E, 0.1-0.2 m; and F, 0.2-0.3 m, under native secondary forest. 
analyzing conventional tillage and no-tillage systems in a Latossolo Vermelho (Rhodic Hapludox), found very low values for $\log \mathrm{K}_{\text {air }}$, even closer to the blocking situation than the one reported here.
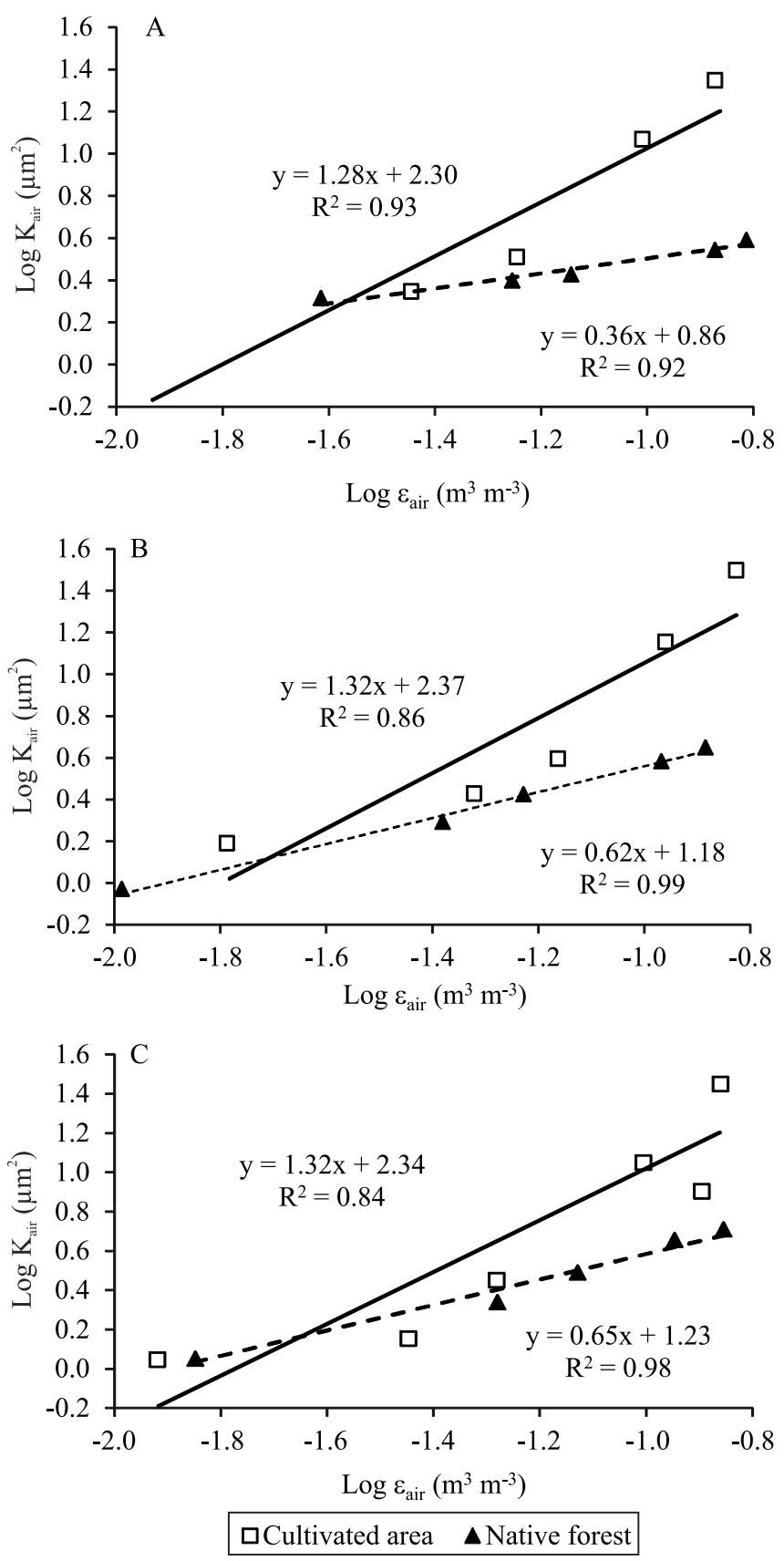

Figure 2. Relationship between soil intrinsic permeability to air $\left(\log \mathrm{K}_{\text {air }}\right)$ and aeration porosity $\left(\log \varepsilon_{\text {air }}\right)$ for an Inceptisol under cultivation with banana (Musa sp.) and under native secondary forest, in the layers: A, $0.0-0.1 \mathrm{~m}$; B, 0.1-0.2 m; and $\mathrm{C}, 0.2-0.3 \mathrm{~m}$.
There was a significant interaction of $\log \mathrm{K}_{\mathrm{air}}$ values between treatments, at the matric potentials of -33 and $-100 \mathrm{kPa}$ (Table 1). At the matric potential of $-2 \mathrm{kPa}$, the pore volume exists but is blocked $\left(\log \mathrm{K}_{\mathrm{air}}=1 \mu \mathrm{m}^{2}\right)$ and does not participate in the convective air transport (although soil gas exchanges occur predominantly through diffusion), in both systems and in all layers analyzed.

This result is specifically important for the cultivated soil, because, when it is very close to saturation, the pores, although empty, do not participate in gas exchanges since they are blocked. This finding indicates a need for an irrigation management that provides water in the shortest time possible or, preferentially, at a rate that does not increase soil water content to an energy level higher than $-2 \mathrm{kPa}$.

The pore continuity index $\mathrm{K}_{1}$, obtained by the ratio between $\mathrm{K}_{\text {air }}$ and $\varepsilon_{\text {air }}$, allows identifying whether the differences in the first are only due to the differences in the second, or whether they are a consequence of the porous space geometry, which depends on diameter distribution, tortuosity, and continuity of pores. For Groenevelt et al. (1984), soils with different $\mathrm{K}_{\text {air, }}$ but similar $\mathrm{K}_{1}$ values, show similar diameter and pore continuity distribution.

In the matric potential interval from -2 to $-10 \mathrm{kPa}$, pore continuity was similar for both soil use systems and even for the different soil layers. However, at the matric potentials of -33 and $-100 \mathrm{kPa}$, except for the layer of $0.1-0.2 \mathrm{~m}$, the pores were either more continuous or less tortuous in the soil cultivated with banana than in the one under secondary forest. This result is similar to those found by Alencar (2014).

It is reasonable to consider that soil intrinsic permeability to air precedes $\varepsilon_{\text {air }}$ regarding limitations for plant growth, since a volume of $0.1 \mathrm{~m}^{3} \mathrm{~m}^{-3}$ of unconnected pores does not meet the minimal condition for proper gas exchange between soil and atmosphere. Actually, Ball et al. (1988) have already reported that the continuity of conductive pores is probably more important than their volume or number. Although the porosity block limit for air flow is already known $\left(1 \mu \mathrm{m}^{2}\right)$, soil physicists must research further the soil intrinsic permeability to air that would allow gas exchange and favor, or at least not restrain, plant growth. This variable could be useful, for instance, to determine the least limiting water range (Beutler et al., 2006).

Pesq. agropec. bras., Brasília, v.51, n.9, p.1575-1583, set. 2016 DOI: 10.1590/S0100-204X2016000900057 
For the cultivated soil, $\mathrm{N}$ values, according to the second equation, were higher than the ones observed in the secondary forest (Table 2), in all layers, besides showing greater pore continuity, as previously discussed. It was evident that the better pore network quality of the soil under cultivation was certainly due to wetting (when irrigated) and to drying (between irrigations), which contribute to the formation of cracks between aggregates, creating preferential paths for air flow. Furthermore, one should not disregard the role of the root system in the formation of root pores. Reports on root effects on soil permeability to air are given by Groenevelt et al. (1984), Uteau et al. (2013), and Chen et al. (2014).

The soil under native secondary forest showed lower volume of blocked pores in all soil layers, when compared with the soil cultivated with banana, which corroborates the results obtained by Alencar (2014) and by Zúñiga et al. (2015). Particularly in the 0.0 $0.1-\mathrm{m}$ soil layer, the soil under secondary native forest showed almost the totality of its pores available for

Table 1. Soil intrinsic permeability to air $\left(\mathrm{K}_{\text {air }}\right)$ and pore continuity index (K1) for an Inceptisol under banana (Musa sp.) cultivation and under native secondary forest, at different depths ${ }^{(1)}$.

\begin{tabular}{|c|c|c|c|c|c|c|}
\hline \multirow[t]{2}{*}{ Soil use } & \multicolumn{3}{|c|}{$\log _{10} \mathrm{~K}_{\text {air }}\left(\mu \mathrm{m}^{2}\right)$} & \multicolumn{3}{|c|}{$\log _{10} \mathrm{~K}_{1}\left(\mu \mathrm{m}^{2}\right)$} \\
\hline & $0.0-0.1 \mathrm{~m}$ & $0.1-0.2 \mathrm{~m}$ & $0.2-0.3 \mathrm{~m}$ & $0.0-0.1$ & $0.1-0.2$ & $0.2-0.3$ \\
\hline & \multicolumn{6}{|c|}{ Matric potential of $-2 \mathrm{kPa}$} \\
\hline Cultivated & -0.084 & 0.142 & 0.085 & 2.08 & 1.82 & 2.08 \\
\hline Native forest & -0.056 & 0.001 & 0.021 & 2.29 & 2.01 & 2.17 \\
\hline \multirow[t]{2}{*}{ Soil use x layers } & ns & ns & $\mathrm{ns}$ & ns & $\mathrm{ns}$ & ns \\
\hline & \multicolumn{6}{|c|}{ Matric potential of $-6 \mathrm{kPa}$} \\
\hline Cultivated & 0.166 & 0.344 & 0.343 & 1.64 & 1.63 & 1.74 \\
\hline Native forest & 0.267 & 0.153 & 0.267 & 1.74 & 1.65 & 1.76 \\
\hline \multirow[t]{2}{*}{ Soil use x layers } & ns & ns & $\mathrm{ns}$ & ns & $\mathrm{ns}$ & $\mathrm{ns}$ \\
\hline & \multicolumn{6}{|c|}{ Matric potential of $-10 \mathrm{kPa}$} \\
\hline Cultivated & 0.474 & 0.394 & 0.529 & 1.74 & 1.57 & 1.76 \\
\hline Native forest & 0.388 & 0.398 & 0.406 & 1.74 & 1.71 & 1.68 \\
\hline \multirow[t]{2}{*}{ Soil use x layers } & ns & ns & $\mathrm{ns}$ & $\mathrm{ns}$ & $\mathrm{ns}$ & $\mathrm{ns}$ \\
\hline & \multicolumn{6}{|c|}{ Matric potential of $-33 \mathrm{kPa}$} \\
\hline Cultivated & $1.035 \mathrm{aA}$ & $0.536 \mathrm{bB}$ & $1.145 \mathrm{aA}$ & $2.05 \mathrm{aA}$ & $1.42 \mathrm{bB}$ & $2.11 \mathrm{aA}$ \\
\hline Native forest & $0.558 \mathrm{bB}$ & $0.999 \mathrm{aA}$ & $0.572 \mathrm{bB}$ & $1.57 \mathrm{bB}$ & $2.03 \mathrm{aA}$ & $1.58 \mathrm{bB}$ \\
\hline \multirow[t]{2}{*}{ Soil use $\mathrm{x}$ layers } & $* *$ & $* *$ & $* *$ & $* *$ & $* *$ & $* *$ \\
\hline & \multicolumn{6}{|c|}{ Matric potential of $-100 \mathrm{kPa}$} \\
\hline Cultivated & $1.305 \mathrm{aA}$ & $0.533 \mathrm{bB}$ & $1.454 \mathrm{aA}$ & $2.18 \mathrm{aA}$ & $1.35 \mathrm{bB}$ & $2.29 \mathrm{aA}$ \\
\hline Native forest & $0.651 \mathrm{bB}$ & $1.264 \mathrm{aA}$ & $0.556 \mathrm{bB}$ & $1.55 \mathrm{bB}$ & $2.13 \mathrm{aA}$ & $1.45 \mathrm{bB}$ \\
\hline Soil use $\mathrm{x}$ layers & $* *$ & $* *$ & $* *$ & $* *$ & $* *$ & $* *$ \\
\hline
\end{tabular}

Pesq. agropec. bras., Brasília, v.51, n.9, p.1575-1583, set. 2016 DOI: 10.1590/S0100-204X2016000900057 gas flow, with only $0.39 \%$ of blocked pores. Despite being out of the scope of the present study, laboratorial analyses showed that, in this layer, the organic carbon content was statistically higher in soil under native secondary forest, which surely contributed to a better porous media quality, especially regarding pore continuity.

Soil water retention and pore distribution frequency are shown in Figure 3. Considering the pores with diameter $\geq 50 \mu \mathrm{m}$ (Libardi, 2012), measured at a tension of $6 \mathrm{kPa}$, the macroporosity of the cultivated soil was: $0.036 \mathrm{~m}^{3} \mathrm{~m}^{-3}$ (7.4\% of total porosity), in the $0.0-0.1-\mathrm{m}$ layer; $0.044 \mathrm{~m}^{3} \mathrm{~m}^{-3}$ (9\% of total porosity) in the $0.1-$ 0.2 -m layer; and $0.034 \mathrm{~m}^{3} \mathrm{~m}^{-3}$ (7.1\% of total porosity) in the $0.2-0.3-\mathrm{m}$ layer. For the soil under secondary forest, these values were: $0.055 \mathrm{~m}^{3} \mathrm{~m}^{-3}(10.9 \%$ of total porosity); $0.038 \mathrm{~m}^{3} \mathrm{~m}^{-3}$ (8.1\% of total porosity); and $0.050 \mathrm{~m}^{3} \mathrm{~m}^{-3}$ (10.7\% of total porosity), respectively.

The soil under native secondary forest had a greater volume of pores, except for the layer of $0.1-0.2 \mathrm{~m}$. However, as previously mentioned, this greater volume did not contribute to a higher intrinsic permeability to air at the tension of $6 \mathrm{kPa}$, because the pore continuity was very similar in both cases. Bouma (1982) observed that large pores may not contribute to the flow when they are discontinuous, while small pores can be good conductors when they have continuity.

The S-index did not show significant differences in soil quality between management systems, either for the same soil layer or between layers (Figure 4). Considering the classes proposed by Dexter \& Czyz (2007), soil quality was characterized as very good, in all situations of soil use and depth. Regarding $\mathrm{S}_{\text {relative, }}$

Table 2. Regression parameters for the relationship between soil intrinsic permeability to air and soil air porosity ${ }^{(1)}$ and the volume of pores blocked for air flow $\left(\varepsilon_{b}\right)$, for an Inceptisol under banana (Musa sp.) cultivation and under native secondary forest, at different depths.

\begin{tabular}{|c|c|c|c|c|c|c|c|c|}
\hline \multirow[t]{2}{*}{$\begin{array}{l}\text { Soil layer } \\
(\mathrm{m})\end{array}$} & \multicolumn{4}{|c|}{$\begin{array}{l}\text { Soil cultivated } \\
\text { with banana }\end{array}$} & \multicolumn{4}{|c|}{$\begin{array}{l}\text { Soil under native } \\
\text { secondary forest }\end{array}$} \\
\hline & $\begin{array}{l}\log \mathrm{M} \\
----\left(\mu \mathrm{m}^{2}\right.\end{array}$ & $\begin{array}{c}\mathrm{N} \\
----\end{array}$ & $\mathrm{R}^{2}$ & $\begin{array}{c}\varepsilon_{\mathrm{b}} \\
(\%)\end{array}$ & $\begin{array}{l}\log \mathrm{M} \\
---\left(\mu \mathrm{m}^{2}\right)\end{array}$ & 2) & $\mathrm{R}^{2}$ & $\begin{array}{c}\varepsilon_{b} \\
(\%)\end{array}$ \\
\hline $0.0-0.1$ & 2.31 & 1.28 & 0.93 & 1.58 & 0.86 & 0.36 & 0.92 & 0.39 \\
\hline $0.1-0.2$ & 2.37 & 1.32 & 0.86 & 1.59 & 1.18 & 0.62 & 0.99 & 1.25 \\
\hline $0.2-0.3$ & 2.34 & 1.32 & 0.84 & 1.69 & 1.23 & 0.65 & 0.98 & 1.26 \\
\hline
\end{tabular}

${ }^{(1)}$ Described by the model: $\log \mathrm{K}_{\text {air }}=\log \mathrm{M}+\mathrm{N} \log \varepsilon_{\text {air }}$, in which $\mathrm{K}_{\text {air }}$ is the soil air intrinsic permeability; $\varepsilon_{\text {air }}$ is the soil air porosity; and $\mathrm{M}$ and $\mathrm{N}$ are empirical fitting parameters. 
both areas were statistically similar in the $0.0-0.1$, $0.1-0.2$, and $0.0-0.3-\mathrm{m}$ soil layers, but different in the $0.2-0.3-\mathrm{m}$ soil layer, in which the soil under cultivation showed improved structure when compared to the secondary forest soil. In addition, in the comparison between layers, the $S_{\text {relative }}$ index detected that the layer of $0.0-0.1 \mathrm{~m}$ had significantly better structure than the other two deeper layers. Therefore, the $\mathrm{S}_{\text {relative }}$ index was more sensitive than the S-index to distinguish changes in soil physical quality.

Besides having a higher sensitivity than the S-index, the $S_{\text {relative }}$ index was also able to quantify the imposed changes to soil structure, because it relativizes them to a standard (textural attributes) that is kept almost unchanged along time. Therefore, once the $\mathrm{S}$ value is obtained for the disturbed reference sample of a given soil, it is possible to obtain the $S_{\text {relative }}$ index at any time in the future, after determining the $\mathrm{S}$ value of different management conditions.

The $\mathrm{S}_{\text {relative }}$ index is promising for the evaluation of soil structure quality, and further studies should include local observation in other soil types, managements, and climates, in order to assess the universality of its application.
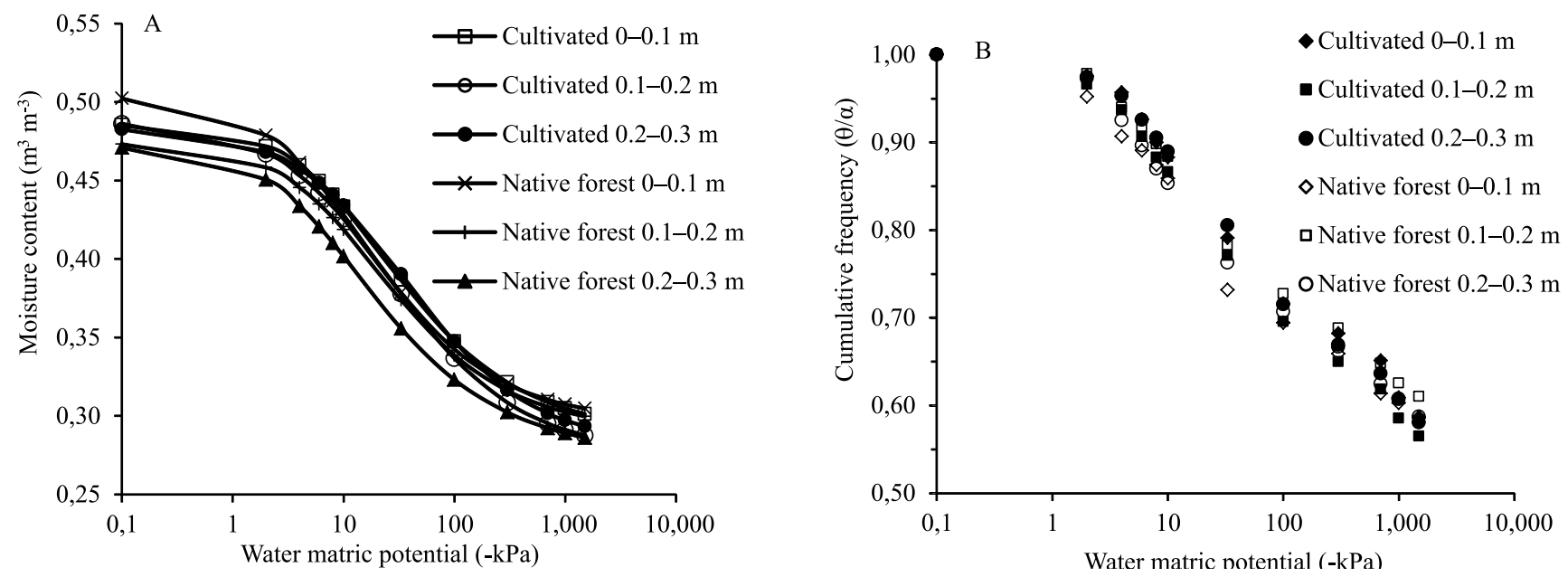

Figure 3. Soil water retention (A) and pore frequency distribution (B) for an Inceptisol under cultivation with banana (Musa sp.) and under native secondary forest, in the layers: $0.0-0.1,0.1-0.2$, and $0.2-0.3 \mathrm{~m}$.

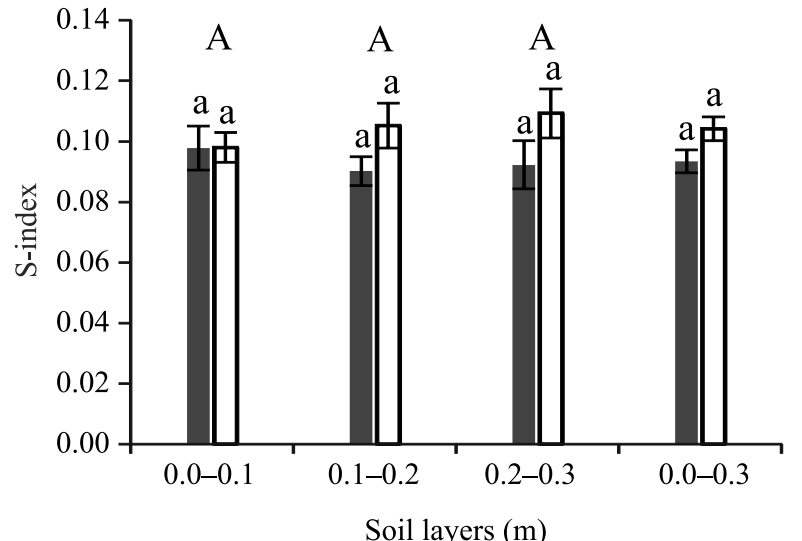

Native forest

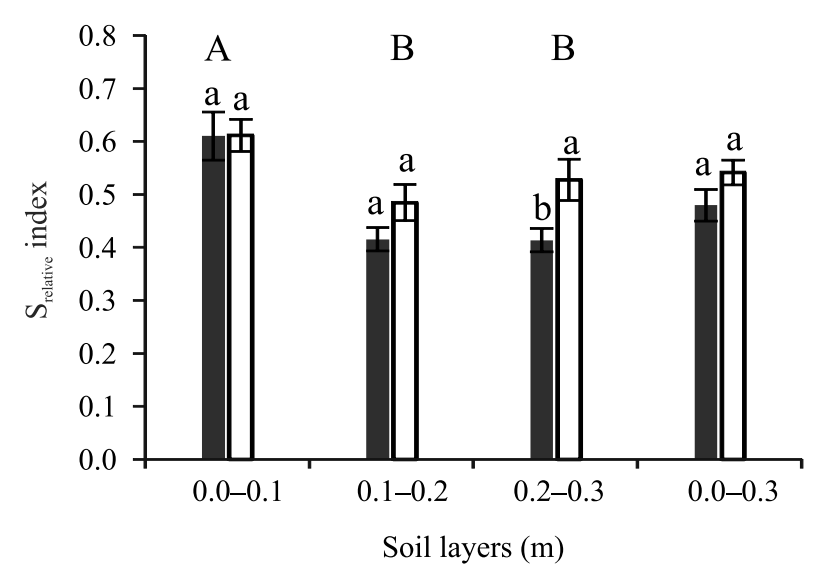

口Cultivated area

Figure 4. S-index and $\mathrm{S}_{\text {relative }}$ index for an Inceptisol under cultivation with banana (Musa sp.) and under native secondary forest. Means followed by equal letters, uppercase between layer means and lowercase between soil use, do not differ by Tukey's test, at $5 \%$ of probability. 


\section{Conclusions}

1. The $S_{\text {relative }}$ index is a sensitive indicator of the effects of soil management on its physical quality.

2. Soil cultivation with banana (Musa sp.) improves, or at least maintains, soil quality attributes, except for blocked porosity, when compared with the soil under native secondary forest with ten years of regeneration after agricultural use.

\section{Acknowledgements}

To Fundação Cearense de Apoio ao Desenvolvimento Científico e Tecnológico (Funcap, project No. 002400013.01.00/10), for financial support.

\section{References}

ALENCAR, T.L. Alterações físicas em um Cambissolo tratado com biofertilizante: indicadores de qualidade e refinamento do método de avaliação pelo $\mathrm{S}_{\text {relativo. }}$ 2014. 92p. Dissertação (Mestrado) - Universidade Federal do Ceará, Fortaleza.

BALL, B.C.; O'SULLIVAN, M.F.; HUNTER, R. Gas diffusion, fluid flow and derived pore continuity indices in relation to vehicle traffic and tillage. Journal of Soil Science, v.39, p.327-339, 1988. DOI: 10.1111/j.1365-2389.1988.tb01219.x.

BERISSO, F.E.; SCHJØNNING, P.; KELLER, T.; LAMANDÉ, M.; SIMOJOKI, A.; IVERSEN, B.V.; ALAKUKKU, L.; FORKMAN, J. Gas transport and subsoil pore characteristics: anisotropy and long-term effects of compaction. Geoderma, v.195-196, p.184191, 2013. DOI: 10.1016/j.geoderma.2012.12.002.

BEUTLER, A.N.; CENTURION, J.F.; SILVA, A.P. da; BARBOSA, J.C. Intervalo hídrico ótimo e produtividade de cultivares de soja. Revista Brasileira de Engenharia Agrícola e Ambiental, v.10, p.639-645, 2006. DOI: 10.1590/S1415-43662006000300015.

BOUMA, J. Measuring the hydraulic conductivity of soil horizons with continuous macropores. Soil Science Society of America Journal, v.46, p.438-441, 1982. DOI: 10.2136/ sssaj1982.03615995004600020047x.

CARDUCCI, C.E.; OLIVEIRA, G.C. de; SEVERIANO, E. da C.; ZEVIANI, W.M. Modelagem da curva de retenção de água de Latossolos utilizando a equação duplo van Genuchten. Revista Brasileira de Ciência do Solo, v.35, p.77-86, 2011. DOI: 10.1590/ S0100-06832011000100007.

CHEN, G.; WEIL, R.R.; HILL, R.L. Effects of compaction and cover crops on soil least limiting water range and air permeability. Soil and Tillage Research, v.136, p.61-69, 2014. DOI: 10.1016/j. still.2013.09.004.

COSTA, P.A. da; MOTA, J.C.A.; ROMERO, R.E.; FREIRE, A.G.; FERREIRA, T.O. Changes in soil pore network in response to twenty-three years of irrigation in a tropical semiarid pasture from northeast Brazil. Soil and Tillage Research, v.137, p.23-32, 2014. DOI: $10.1016 /$ j.still.2013.11.004.
DEXTER, A.R. Soil physical quality. Part I. Theory, effects of soil texture, density, and organic matter, and effects on root growth. Geoderma, v.120, p.201-214, 2004. DOI: 10.1016/j. geoderma.2003.09.004.

DEXTER, A.R.; CZYZ, E.A. Applications of S-theory in the study of soil physical degradation and its consequences. Land Degradation and Development, v.18, p.369-381, 2007. DOI: 10.1002/ldr.779.

DÖRNER, J.; HORN, R. Anisotropy of pore functions in structured Stagnic Luvisols in the Weichselian moraine region in N Germany. Journal of Plant Nutrition and Soil Science, v.169, p.213-220, 2006. DOI: $10.1002 / j p l n .200521844$.

GIAROLA, N.F.B.; SILVA, A.P. da; TORMENA, C.A.; BALL, B.; ROSA, J.A. Visual soil structure quality assessment on Oxisols under no-tillage system. Scientia Agricola, v.67, p.479-482, 2010. DOI: $10.1590 / \mathrm{S} 0103-90162010000400016$.

GROENEVELT, P.H.; KAY, B.D.; GRANT, C.D. Physical assessment of a soil with respect to rooting potential. Geoderma, v.34, p.101-114, 1984. DOI: 10.1016/0016-7061(84)90016-8.

KLUTE, A. Water retention: laboratory methods. In: KLUTE, A. (Ed.). Methods of soil analysis. $2^{\text {nd }}$ ed. Madison: American Society of Agronomy, Soil Science Society of America, 1986. p.635-662. (SSSA. Agronomy monography, 9). DOI: 10.2136/ sssabookser5.1.2ed.c26.

LIBARDI, P.L. Dinâmica da água no solo. 2.ed. Piracicaba: Edusp, 2012. 352p.

REICHARDT, K.; TIMM, L.C. Solo, planta e atmosfera: conceitos, processos e aplicações. 2.ed. Barueri: Manole, 2012. 524p.

RODRIGUES, S.; SILVA, A.P. da; GIAROLA, N.F.B.; ROSA, J.A. Permeabilidade ao ar em Latossolo Vermelho sob diferentes sistemas de manejo. Revista Brasileira de Ciência do Solo, v.35, p.105-114, 2011. DOI: $10.1590 / \mathrm{S} 0100-06832011000100010$.

SILVA, A.P. da; LEÃO, T.P.; TORMENA, C.A.; GONÇALVES, A.C.A. Determinação da permeabilidade ao ar em amostras indeformadas de solo pelo método da pressão decrescente. Revista Brasileira de Ciência do Solo, v.33, p.1535-1545, 2009. DOI: 10.1590/S0100-06832009000600003.

SILVA, F.A.S. Assistat software. 2013. Available at: $<$ http://www. assistat.com/indexp.html >. Accessed on: Dec. 82015.

UTEAU, D.; PAGENKEMPER, S.K.; PETH, S.; HORN, R. Root and time dependent soil structure formation and its influence on gas transport in the subsoil. Soil and Tillage Research, v.132, p.69-76, 2013. DOI: 10.1016/j.still.2013.05.001.

VAN GENUCHTEN, M. Th. A closed-form equation for predicting the conductivity of unsaturated soils. Soil Science Society of America Journal, v.44, p.892-897, 1980. DOI: 10.2136/ sssaj1980.03615995004400050002x.

VAN LIER, Q. de J. Revisiting the S-index for soil physical quality and its use in Brazil. Revista Brasileira de Ciência do Solo, v.38, p.1-10, 2014. DOI: 10.1590/S0100-06832014000100001.

YEOMANS, J.C.; BREMMER, J.M. A rapid and precise method for routine determination of organic carbon in soil. Communications in Soil Science and Plant Analysis, v.19, p.1467-1476, 1988. DOI: $10.1080 / 00103628809368027$. 
ZHAO, Y.; KRZIC, M.; BULMER, C.E.; SCHMIDT, M.G.; SIMARD, S.W. Relative bulk density as a measure of compaction and its influence on tree height. Canadian Journal of Forest Research, v.40, p.1724-173, 2010. DOI: $10.1139 / \mathrm{X} 10-115$.
ZÚÑIGA, F.; IVELIC-SÁEZ, J.; LÓPEZ, I.; HUYGENS, D.; DÖRNER, F.J. Temporal dynamics of the physical quality of an Andisol under a grazing system subjected to different pasture improvement strategies. Soil and Tillage Research, v.145, p.233241, 2015. DOI: 10.1016/j.still.2014.09.014.

Received on June 25, 2015 and accepted on February 12, 2016 